Article

\title{
An Experimental Study on the Performance and Emission of the diesel/CNG Dual-Fuel Combustion Mode in a Stationary CI Engine
}

\author{
Arkadiusz Jamrozik *(1), Wojciech Tutak and Karol Grab-Rogaliński \\ Faculty of Mechanical Engineering and Computer Science, Czestochowa University of Technology, 42-201 \\ Czestochowa, Poland; tutak@imc.pcz.pl (W.T.); grab@imc.pcz.pl (K.G.-R.) \\ * Correspondence: jamrozik@imc.pcz.pl
}

Received: 23 September 2019; Accepted: 8 October 2019; Published: 12 October 2019

\begin{abstract}
One of the possibilities to reduce diesel fuel consumption and at the same time reduce the emission of diesel engines, is the use of alternative gaseous fuels, so far most commonly used to power spark ignition engines. The presented work concerns experimental research of a dual-fuel compression-ignition (CI) engine in which diesel fuel was co-combusted with CNG (compressed natural gas). The energy share of CNG gas was varied from $0 \%$ to $95 \%$. The study showed that increasing the share of $\mathrm{CNG}$ co-combusted with diesel in the $\mathrm{CI}$ engine increases the ignition delay of the combustible mixture and shortens the overall duration of combustion. For CNG gas shares from $0 \%$ to $45 \%$, due to the intensification of the combustion process, it causes an increase in the maximum pressure in the cylinder, an increase in the rate of heat release and an increase in pressure rise rate. The most stable operation, similar to a conventional engine, was characterized by a diesel co-combustion engine with $30 \%$ and $45 \%$ shares of CNG gas. Increasing the CNG share from $0 \%$ to $90 \%$ increases the nitric oxide emissions of a dual-fuel engine. Compared to diesel fuel supply, co-combustion of this fuel with $30 \%$ and $45 \%$ CNG energy shares contributes to the reduction of hydrocarbon ( $\mathrm{HC}$ ) emissions, which increases after exceeding these values. Increasing the share of CNG gas co-combusted with diesel fuel, compared to the combustion of diesel fuel, reduces carbon dioxide emissions, and almost completely reduces carbon monoxide in the exhaust gas of a dual-fuel engine.
\end{abstract}

Keywords: CNG; diesel fuel; dual fuel engine; rate of heat release; ignition delay; burn duration; exhaust gas emission

\section{Introduction}

The piston-based internal combustion engine is a heat machine, which is still the most common device for driving motor vehicles and various types of working machines [1]. Currently, internal combustion engines are increasingly used in stationary solutions, in small distributed energy, as a source of propulsion for cogeneration units, generating electricity and heat (CHP) for the needs of the local market [2,3]. For stationary applications, there is a wide range of internal combustion engines, both spark ignition and compression ignition. Stationary internal combustion engines are very often built as compression-ignition diesel engines, which have a number of advantages compared to spark-ignition engines. The most important of them are: higher reliability, fuel economy, higher power range, longer life, faster response to power demand and higher torque. Diesel fuel obtained from crude oil is a typical fuel supplying compression-ignition (CI) engines. The combustion of this type of fuel is accompanied by the emission of harmful compounds, such as carbon monoxide, carbon dioxide, hydrocarbons, nitrogen oxides and soot $[4,5]$. The vision of the depletion of oil resources, and 
the impact of $\mathrm{CO}_{2}$, as a greenhouse gas, on the rise in the average temperature on Earth are widely known. To counteract this, restrictive emission standards, bans on vehicles with combustion engines entering city centers, or EU directives on the use of alternative and renewable energy sources have been introduced [6,7]. One of the possibilities to reduce the combustion of diesel fuel and at the same time reduce the emission of diesel engines is the use of alternative fuels, so far most commonly used to power spark ignition engines [8,9]. Most of that type of alternative fuels, however, due to their properties, cannot be burned independently in a compression-ignition engine; therefore, in recent years research has been ongoing on the technology of the co-combustion of alternative fuels with diesel in a dual-fuel engine [10]. Alternative fuels include hydrocarbon gas fuels [11,12]. The increase in interest in supplying combustion engines with hydrocarbon gas fuels observed in the last several years is caused by two important features of these fuels. The first is the low cost of energy obtained from them. The prices of gaseous fuels on European markets allow obtaining a cost of energy unit at the level of $30-50 \%$ in the case of natural gas and $40-60 \%$ in the case of liquefied gas, in relation to the cost of the energy unit contained in liquid fossil fuels. The second feature is the favorable ecological properties of gaseous fuels. Natural gas, unlike other fossil fuels such as coal and oil, due to its advantages, is one of the gaseous fuels that are increasingly used in the automotive industry, large energy and local distributed energy based on internal combustion engines [13,14]. Most often, natural gas is used in compressed form as CNG (compressed natural gas) [15]. CNG is a fuel increasingly used in dual-fuel compression-ignition engines, both naturally aspirated and supercharged [16,17]. Meng et al. [18] studied the co-combustion of a mixture of diesel fuel and n-butanol with CNG gas in a dual-fuel diesel engine. The use of a mixture of diesel fuel and n-butanol as a dose of pilot fuel was intended to improve engine performance and emissions. Three types of pilot-doses were used in the studies, including B0 (pure diesel), B10 (90\% diesel and 10\% n-butanol) and B20 (80\% diesel and $20 \%$ n-butanol). Experiments were carried out for two loads, at different pilot-dose injection angles. Different CNG gas shares were analyzed for each load. For the first load ( 5 bar IMEP), the share of CNG gas was 60 and 80\%. For B10CNG40, the highest thermal efficiency (ITE) and the lowest THC (total hydrocarbons) emissions were obtained with a slight increase in $\mathrm{NO}_{\mathrm{x}}$. For B20CNG70, a decrease in $\mathrm{NO}_{\mathrm{x}}$ emission was obtained due to better homogeneity of the combustible mixture and higher latent heat of vaporization of n-butanol. In the case of higher loads (7.5 bar IMEP), the shares of CNG gas were $60 \%$ and $80 \%$. For B10CNG60 and B20CNG60 compared to B10CNG80 and B20CNG80, ITE improvement and reduction of THC emissions were achieved, while the level of $\mathrm{NO}_{\mathrm{x}}$ emissions remained constant. Ryu $[19,20]$ conducted research on a single-cylinder, dual-fuel diesel engine fueled with biodiesel and CNG. In that experiment, he used a biodiesel pilot-dose injection to ignite the main charge consist of air and compressed natural gas (CNG). In paper [19], he studied the impact of pilot-dose injection angle on combustion characteristics, engine performance and emissions at a constant injection pressure of about $120 \mathrm{MPa}$, and a change in injection angle in the range of $11^{\circ}$ to $23^{\circ}$ before TDC. The results showed that engine performance can be improved by optimizing the start angle of biodiesel and CNG co-combusting. Improvement in performance, including a reduction in specific fuel consumption for low loads, was achieved due to the earlier angle of pilot-dose injection, while for high loads, it was beneficial to delay the injection angle of pilot-dose. The use of biodiesel-CNG dual fuel combustion mode compared to diesel single combustion mode caused a delay in ignition of the charge in the engine cylinder. The ignition delay decreased as the engine load increased. For the dual fuel engine compared to a conventional diesel engine, there was reduced smoke opacity, and $\mathrm{NO}_{\mathrm{x}}$ and $\mathrm{CO}_{2}$ emissions. In addition, relatively high $\mathrm{CO}$ and hydrocarbon $(\mathrm{HC})$ emissions were obtained, especially under low load conditions, due to the low combustion temperature of CNG. The article [20] presents the results of research on the impact of biodiesel pilot injection pressure on performance and exhaust emissions during co-combustion of biodiesel and CNG. The results show that the indicated mean effective pressure (IMEP) for biodiesel-CNG dual fuel combustion mode is lower compared to Diesel single combustion mode, with the injection pressure increased above $30 \mathrm{MPa}$. Increasing the injection pressure resulted in a reduction in ignition delay and a reduction of combustion time, as well 
as a reduction of exhaust gas smoke opacity and an increase in $\mathrm{NO}_{\mathrm{x}}$ emissions. The combustion stability of a dual-fuel engine increased with increasing injection pressure. Bari and Hossain [21] conducted experiments to examine the efficiency of a diesel engine fueled with CNG and diesel in dual-fuel mode, with various proportions of diesel, ranging from $10 \%$ to $100 \%$. The tests were carried out for several selected engine loads. The results showed that the co-combustion of CNG and diesel, compared to the combustion of pure diesel, leads to a reduction in engine efficiency (BTE-brake thermal efficiency) and an increase in specific fuel consumption (BSFC). The largest decrease in efficiency and increase in fuel consumption was recorded for the smallest load-1.1 kW. At that load, BSFC growth was $68 \%$. Analyses of exhaust gas composition have shown that the use of CNG to power a dual-fuel engine leads to a reduction in smoke and $\mathrm{CO}_{2}$ emissions and an increase in $\mathrm{CO}$ emissions. The performances and emissions of dual-fuel compression-ignition engines are significantly influenced by the moment of starting the combustion process, which depends on the injection time of the pilot fuel dose and the amount of fuel. Liu et al. [22] studied the emission characteristics of a dual-fuel engine powered by CNG and diesel with the optimization of injection angle and various amounts of a diesel fuel pilot-dose. The results of the experiments showed that the $\mathrm{CO}$ emission in the dual-fuel engine was much higher and the $\mathrm{NO}_{x}$ emission was on average $30 \%$ lower compared to a conventional diesel engine. HC emissions in dual-fuel combustion mode are higher, especially at low and medium loads. In the partial load range, natural gas used in dual-fuel compression-ignition engines very often leads to reduced performance and reduced emissions. In order to eliminate some disadvantages of CNG gas, Karabektas et al. [23] proposed in a diesel-CNG dual-fuel engine, modification of the pilot fuel dose composition by adding diethyl ether (DEE) to diesel fuel. The research concerned the combustion of diesel alone, the co-combusting of diesel with $40 \%$ CNG and the co-combusting of diesel and DEE with $40 \%$ CNG. The pilot-doses of DEE were $5 \%$ and $10 \%$. It was found that the co-combustion of diesel fuel with CNG gas compared to the combustion of diesel fuel alone causes deterioration of engine performance, especially at low and medium loads. In addition, it has higher $\mathrm{CO}$ and $\mathrm{HC}$ emissions at all loads and lower $\mathrm{NO}_{\mathrm{x}}$ emissions at high loads. The use of DEE as an additive to a pilot-dose leads to an improvement in thermal efficiency and a reduction in specific energy consumption, resulting in lower $\mathrm{CO}$ and $\mathrm{NO}_{\mathrm{x}}$ emissions.

The present work concerns tests of a stationary compression-ignition engine, adapted for dual-fuel operation, in which diesel fuel was combined with CNG (compressed natural gas). As part of the work, experimental studies were carried out on the impact of the CNG gas's energy share on selected engine operating parameters; i.e., cylinder pressure, pressure increase rate, heat release rate, autoignition delay or combustion time, and an analysis of harmful compounds' emissions in this engine exhaust gas was performed. As part of the presented research, an assessment was also performed, of the stability of operation of a dual-fuel diesel and CNG engine. In the available literature is a lack of sufficient information on that type of analysis. The engine stability, manifested in the uniqueness of subsequent cycles, was analyzed. This was determined on the basis of changes in the value of the uniqueness coefficient of the maximum pressure- $\mathrm{COV}_{\text {pmax }}$ and the probability density of the occurrence of the maximum pressure $-\Phi\left(\mathrm{p}_{\max }\right)$. The tests were carried out for a wide range of CNG energy shares, from $0 \%$ to $95 \%$.

\section{Experimental Methodology}

\subsection{Experimental Setup}

The research carried out as part of the study was experimental, in which the object of the study was a single-cylinder, naturally aspirated four-stroke diesel engine, Andoria 1CA90. This engine is a stationary, two-valve unit, with a vertical cylinder arrangement, in which an air-cooling system with an axial fan is used. The engine was designed to work with a constantly maximal load, at a constant rotation speed of $1500 \mathrm{rpm}$. The engine was adapted for dual-fuel operation by equipping it with an additional CNG gas supply system, injected under a pressure of approximately 3 bar into the 
intake manifold. The Servojet SP051S1 gas injector was operated by an external control system that made it possible to synchronize the injector with the engine and precisely control its opening time. This allowed for correct and even gas injecting during the suction stroke. Based on earlier tests of this engine, it was determined that the optimal diesel injection angle is $17^{\circ}$ before TDC [24]. Figure 1 shows a diagram of a test bench with a test engine, while Table 1 shows the technical data of the 1CA90 engine. The stand was equipped with a system for measuring and recording combustion pressure in the engine cylinder, and systems for measuring the consumption of liquid fuel and gaseous fuel, air consumption, and the contents of engine exhaust components. Table 2 presents the parameters of the exhaust gas analyzer used during the tests. The pressure measurement system consisted of a piezoelectric pressure sensor, load amplifier, crankshaft angle sensor and data acquisition system with an analog-to-digital converter.

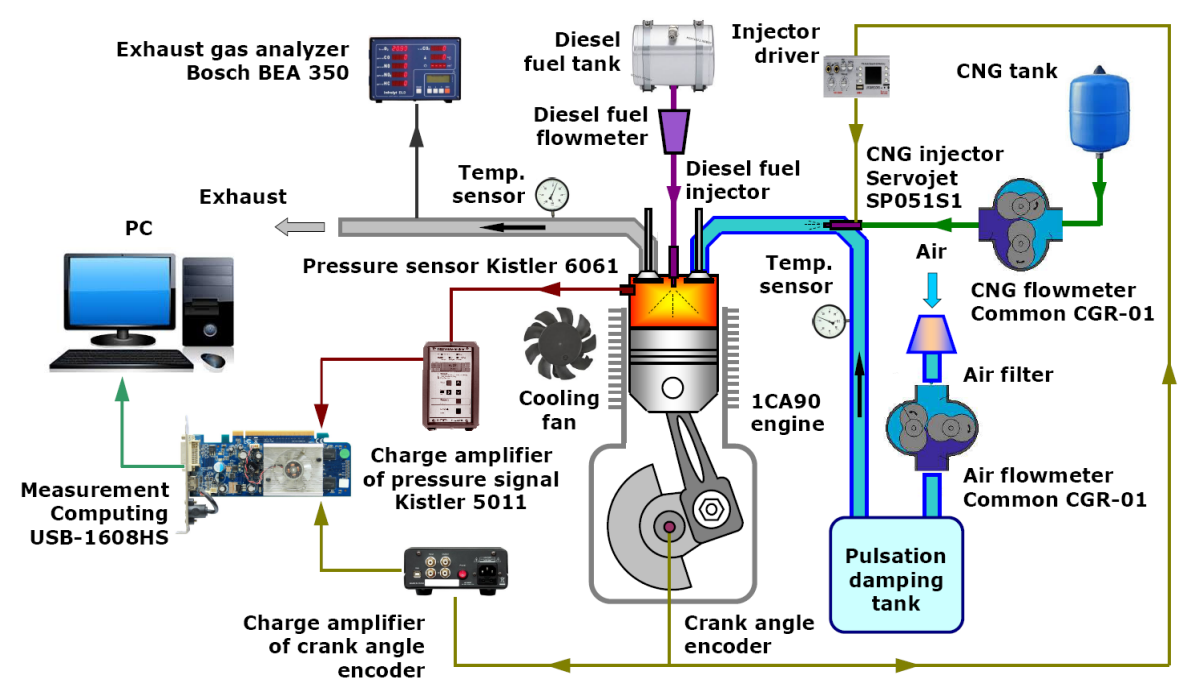

Figure 1. Schematic diagram of the experimental setup.

Table 1. Main engine parameters.

\begin{tabular}{cc}
\hline Parameter & Value \\
\hline Engine & 1CA90 Andoria \\
\hline Type of engine & four stroke compression-ignition \\
\hline Number of cylinders & 1 \\
\hline Bore & $90 \mathrm{~mm}$ \\
\hline Stroke & $90 \mathrm{~mm}$ \\
\hline Displaced volume & $573 \mathrm{~cm}^{3}$ \\
\hline Number of valves & 2 \\
\hline Compression ratio & 17 \\
\hline Engine speed & $1500 \mathrm{rpm}$ \\
\hline Diesel injection & direct injection \\
\hline CNG injection & port injection \\
\hline Diesel injection pressure & 210 bar \\
\hline CNG injection pressure & 3 bar \\
\hline Diesel injection timing & $343^{\circ}$ \\
\hline
\end{tabular}

The study used the following measurement apparatus:

(i) Pressure sensor Kistler 6061—range 0-250 bar, linearity $< \pm 0.5 \%$ FS; 
(ii) Charge amplifier Kistler 5011—range $\pm 10- \pm 999,000$ pC for 10V FS, error $< \pm 3 \%$, linearity $< \pm$ $0.05 \% \mathrm{FS}$;

(iii) Data acquisition module, Measurement Computing USB-1608HS-16 bits resolution, sampling frequency $20 \mathrm{kHz}$;

(iv) Air rotor flowmeter Common CGR-01 G40 DN50-measuring range $0.65-65 \mathrm{~m}^{3} / \mathrm{h}$, accuracy class 1;

(v) CNG rotor flowmeter Common CGR-01 G10 DN50-measuring range $0.25 \ldots 25 \mathrm{~m}^{3} / \mathrm{h}$, accuracy class 1;

(vi) Bosch BEA 350 analyzer.

Table 2. Parameters of the Bosch BEA 350 analyzer [25].

\begin{tabular}{|c|c|c|c|c|}
\hline Apparatus & Measuring Range & Resolution & $\begin{array}{l}\text { Accuracy from } \\
\text { Measured Value }\end{array}$ & $\begin{array}{l}\text { Absolute } \\
\text { Accuracy }\end{array}$ \\
\hline $\mathrm{CO}$ & $\begin{array}{l}0.000-10.000 \% \text { vol. } \\
0.000-5.000 \% \text { vol. }\end{array}$ & $\begin{array}{l}0.001 \% \text { vol. } \\
0.001 \% \text { vol. }\end{array}$ & $\begin{array}{c}\ldots \\
\pm 5 \%\end{array}$ & $\pm 0.06 \%$ vol. \\
\hline $\mathrm{HC}$ & $\begin{array}{l}\text { 0-9999 ppm vol. } \\
\text { 0-2000 ppm vol. }\end{array}$ & $\begin{array}{l}1 \text { ppm vol. } \\
1 \text { ppm vol. }\end{array}$ & $\begin{array}{r}\cdots \\
\pm 5 \% \\
\end{array}$ & $\begin{array}{c}\ldots \\
\pm 12 \text { ppm vol. }\end{array}$ \\
\hline $\mathrm{CO}_{2}$ & $\begin{array}{l}0.00-18.00 \% \text { vol. } \\
0.00-16.00 \% \text { vol. }\end{array}$ & $\begin{array}{l}0.01 \% \text { vol. } \\
0.01 \% \text { vol. }\end{array}$ & $\begin{array}{c}\ldots \\
\ldots 5 \% \\
\pm\end{array}$ & $\begin{array}{c}\ldots \\
\pm 0.5 \% \text { vol. }\end{array}$ \\
\hline $\mathrm{O}_{2}$ & $\begin{array}{l}0.00-22.00 \% \text { vol. } \\
0.00-21.00 \% \text { vol. }\end{array}$ & $\begin{array}{l}0.01 \% \text { vol. } \\
0.01 \% \text { vol. }\end{array}$ & $\begin{array}{c}\ldots \\
\pm 4 \%\end{array}$ & $\begin{array}{c}\ldots \\
\pm 0.1 \% \text { vol. }\end{array}$ \\
\hline $\mathrm{NO}$ & $\begin{array}{l}\text { 0-5000 ppm vol. } \\
\text { 0-4000 ppm vol. }\end{array}$ & $\begin{array}{l}1 \text { ppm vol. } \\
1 \text { ppm vol. }\end{array}$ & $\begin{array}{l} \pm 4 \% \\
\pm 8 \% \\
\end{array}$ & $\begin{array}{l} \pm 25 \text { ppm vol. } \\
\pm 50 \text { ppm vol. }\end{array}$ \\
\hline$\lambda$ & $\begin{array}{l}0.500-9.999 \\
0.700-1.300\end{array}$ & $\begin{array}{l}0.001 \\
0.001\end{array}$ & $\begin{array}{c}\ldots \\
\pm 4 \%\end{array}$ & $\begin{array}{l}\cdots \\
\cdots\end{array}$ \\
\hline
\end{tabular}

\subsection{Methodology}

During the tests, the engine was operated at full load and rotational speed dedicated to the serial engine. The tests were carried out after thermal stabilization of the engine. The tests were carried out at the factory settings of the serial engine, for which there was no knocking problem. Increasing the energy share of CNG gas consisted of a gradual increase in the gas injector opening time, while reducing the amount of diesel fuel fed. The energy dose of the two fuels supplied to the engine cylinder was kept approximately constant, corresponding to $1500 \mathrm{~J}$ per cycle. The main scope of research included recording the value of variable pressure in the cylinder of the research engine, every 1 degree of crank angle for three measurements containing 200 subsequent engine cycles. The program used for recording and analyzing in real time the pressure signal in the cylinder during the engine running used an experimental pressure recording system as a function of the crankshaft rotation angle, based on a data acquisition module with an A/D converter, a piezoelectric pressure sensor and a crankshaft rotation angle marker. In addition, engine speed, air consumption, diesel fuel consumption, CNG gas consumption, air temperature, exhaust gas temperature and ambient pressure and temperature were measured during the tests. The first stage of the experiment concerned the testing of an engine running on diesel alone as a reference fuel. The next, primary part of the work included tests of the engine working in a dual-fuel system, with the engine fed with diesel fuel and compressed natural gas. These studies were conducted for a wide range of CNG energy shares: from 30\% to $95 \%$.

\subsection{Test Fuels}

Diesel fuel, offered by the Polish refinery, was used as the reference fuel in the analysis, which is used in combination with liquid hydrocarbons separated from oil lubrication in the distillation processes. The fuel used includes the quality standards defined in the PN-EN 590 standard, applicable on the 
markets of the European Union and are available for motor vehicles equipped with compression-ignition engines. The key parameter of diesel fuel is the cetane number determining the ability of a fuel for auto-ignition under the influence of high temperature. The minimum value of the cetane number of diesel fuel offered on the Polish market, guaranteeing meeting the requirements related to the operation of the engine in various conditions of use, is 51 and is determined by regulations. Another important parameter of motor fuel is the calorific value, which determines the amount of heat released when burning a mass unit or a unit of fuel volume. The calorific value of diesel fuel is about $42.5 \mathrm{MJ} / \mathrm{kg}$. The alternative fuel co-cobusted with diesel was CNG compressed natural gas. In practical applications, CNG is used in both spark-ignition engines and compression-ignition engines. In the CI engine, due to the low cetane number, close to 0 , and high auto-ignition temperature $\left(650^{\circ} \mathrm{C}\right)$, a small amount of diesel fuel injection is used to ignite the air and natural gas mixture, whose task is to create self-ignition regions to initiate combustion [26]. The pro-ecological properties of natural gas are due to the fact that its main combustible component is methane- $\mathrm{CH}_{4}$, the content of which ranges from $90 \%$ to $99 \%$ depending on the gas source. Methane is the simplest hydrocarbon, with one carbon atom, widely regarded as a non-toxic component. Due to the fact that in methane has up to four hydrogen atoms per one carbon atom, as a result of its combustion, about $24.5 \%$ less carbon dioxide is created compared to traditional liquid fuels [27]. Natural gas also includes hydrocarbons with a lower hydrogen to carbon ratio, such as ethane, propane, butane and pentane. The calorific value of CNG gas, compared to diesel, is higher and amounts to approximately $49 \mathrm{MJ} / \mathrm{kg}$. Table 3 presents the basic properties of diesel fuel and CNG gas, while Table 4 presents the composition of natural gas.

Table 3. Fuel specifications.

\begin{tabular}{ccc}
\hline Parameter & Diesel & CNG \\
\hline Cetane number & 51 & 0 \\
\hline Methane number & - & 82 \\
\hline Research octane number & $15-25$ & $110-130$ \\
\hline Density at 1 atm and $15^{\circ} \mathrm{C}\left(\mathrm{kg} / \mathrm{m}^{3}\right)$ & 840 & $0.72-0.76$ \\
\hline Lower heating value $(\mathrm{MJ} / \mathrm{kg})$ & 42.5 & 49.15 \\
\hline Heat of evaporation $(\mathrm{kJ} / \mathrm{kg})$ & 243 & 510 \\
\hline Auto-ignition temperature $\left({ }^{\circ} \mathrm{C}\right)$ & $180-230$ & 650 \\
\hline Stoichiometric air-fuel ratio & 14.6 & 17.05 \\
\hline Viscosity at $20{ }^{\circ} \mathrm{C}(\mathrm{Pa} \cdot \mathrm{s})$ & $2.8 \times 10^{-3}$ & $1-1.4 \times 10^{-6}$ \\
\hline Boiling point $\left({ }^{\circ} \mathrm{C}\right)$ & $180-360$ & -162 \\
\hline Carbon content $(\%)$ & 85 & 75 \\
\hline
\end{tabular}

In the presented research, the process of co-combustion diesel fuel with CNG gas in a dual-fuel diesel engine was analyzed for CNG energy shares varying from $0 \%$ to $95 \%$. The amount of energy in diesel fuel and CNG gas that was supplied to the engine cylinder for one work cycle was approximately constant and close to $1500 \mathrm{~J} /$ cycle (Figure 2a). With the change in the share of both co-combusted fuels, the total mass of fuel, due to different calorific values of diesel and CNG, was different. With the increase in the share of CNG gas, the total fuel mass decreased from 34.88 to $26.61 \mathrm{mg} /$ cycle (Figure 2b). 
Table 4. Compressed natural gas (CNG) composition.

\begin{tabular}{cc}
\hline Component & $v / v(\%)$ \\
\hline Methane $\mathrm{CH}_{4}$ & 96.1 \\
\hline Ethane $\mathrm{C}_{2} \mathrm{H}_{6}$ & 2.50 \\
\hline Propane $\mathrm{C}_{3} \mathrm{H}_{8}$ & 0.40 \\
\hline Butane $\mathrm{C}_{4} \mathrm{H}_{10}$ & 0.14 \\
\hline Pentane $\mathrm{C}_{5} \mathrm{H}_{12}$ & 0.01 \\
\hline Nitrogen $\mathrm{N}_{2}$ & 0.59 \\
\hline Carbon dioxide $\mathrm{CO}_{2}$ & 0.15 \\
\hline
\end{tabular}
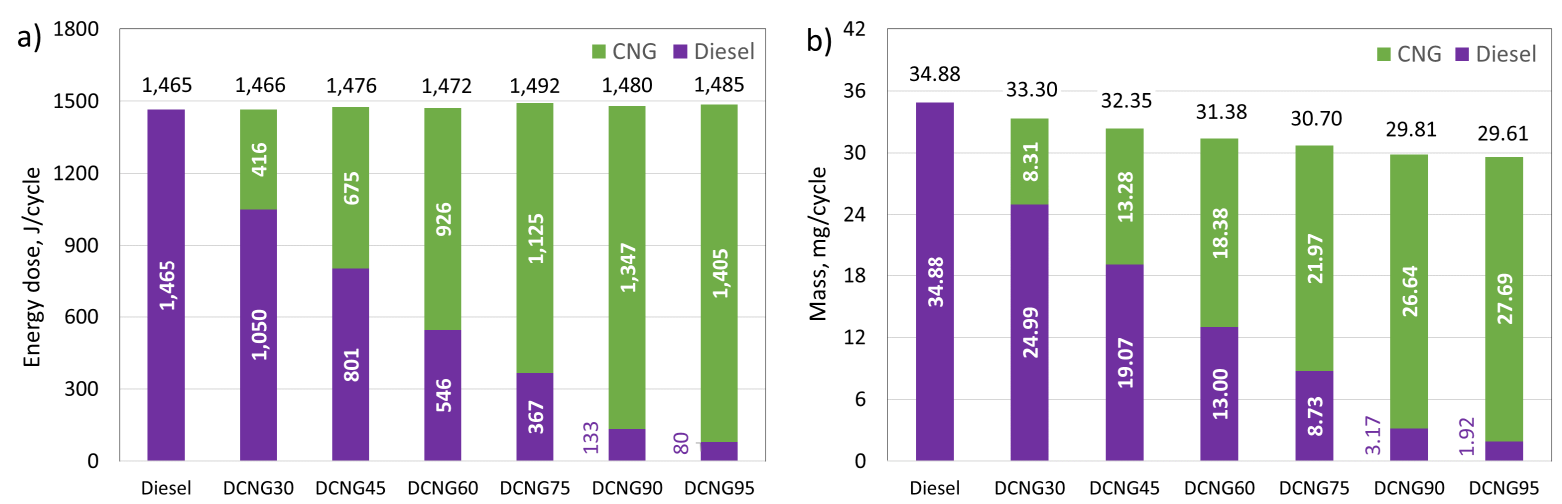

Figure 2. Energy (a) and mass (b) of the fuel delivered to the engine per one work cycle.

\section{Test Method and Conditions}

The study examined the impact of the energy share of compressed natural gas in the air-fuel mixture during co-combustion of this gas with diesel fuel on selected parameters of the combustion process. The energy share of CNG was calculated based on the equation:

$$
\mathrm{CNG} \%=\frac{\dot{\mathrm{m}}_{\mathrm{CNG}} \mathrm{LHV}_{\mathrm{CNG}}}{\dot{\mathrm{m}}_{\mathrm{CNG}} \mathrm{LHV}_{\mathrm{CNG}}+\dot{\mathrm{m}}_{\mathrm{D}} \mathrm{LHV}_{\mathrm{D}}} 100 \%,
$$

where $\dot{\mathrm{m}}_{\mathrm{CNG}}$ and $\dot{\mathrm{m}}_{\mathrm{D}}$ correspond to $\mathrm{CNG}$ gas and diesel fuel consumption per engine cycle, $\mathrm{LHV}_{\mathrm{CNG}}$ and $L H V_{D}$, respectively, represent the calorific values of CNG gas and diesel.

The heat release rate (HRR) is one of the indicators characterizing the combustion process in an internal combustion engine cylinder. HRR can be determined on the basis of registered changes in pressure in the cylinder, from the cylinder pressure graph, by calculating the changes in internal energy and the indicated work factor. Heat release rate:

$$
\mathrm{HRR}=\frac{1}{x-1}\left[x p \frac{\mathrm{dV}}{\mathrm{df}}+\mathrm{V} \frac{\mathrm{dp}}{\mathrm{df}}\right]
$$

where $\chi$ is the ratio of specific heats, $\mathrm{V}$ is cylinder volume and $\mathrm{p}$ is in the cylinder pressure.

The nature of the work of a diesel engine is significantly influenced by the value of the pressure rise rate. The rate of pressure rise $\mathrm{dp} / \mathrm{d} \varphi$ was determined:

$$
\frac{\mathrm{dp}}{\mathrm{df}}=\frac{\mathrm{p}_{\mathrm{k}}-\mathrm{p}_{\mathrm{k}-1}}{\mathrm{f}_{\mathrm{k}}-\mathrm{f}_{\mathrm{k}-1}},
$$


where $p$ is in cylinder pressure, $\varphi$ is crank angle and $k$ is a current angle of crankshaft rotation for engine cycle.

Based on the combustion pressure charts, characteristic values representative of many individual engine cycles, such as average maximum combustion pressure, can be determined. Changes in these quantities can be calculated using statistical analysis methods and presented as coefficients of variation for the maximum pressure $\left(\mathrm{COV}_{\mathrm{pmax}}\right)$ [28].

The average value of maximum pressure $p_{\max }$, determined with the set of pressures, is:

$$
\overline{\mathrm{p}}_{\max }=\frac{1}{\mathrm{~N}} \sum_{\mathrm{i}=1}^{\mathrm{N}} \mathrm{p}_{\operatorname{maxi}}
$$

where $\mathrm{N}$ is the cycle index, $\mathrm{p}_{\max } \mathrm{i}$ is the maximum pressure in individual cycles and $i$ is the cycle number.

One of the most commonly used criteria for assessing the correct operation of an internal combustion engine is its cycle-by-cycle variation. As a measure of the cycle-by-cycle variation of the engine, the coefficient of variation for the maximum pressure $\mathrm{COV}_{\text {pmax }}$ can be taken, expressed as a percentage, and calculated as the ratio of the maximum standard pressure deviation to its average value over many recorded engine cycles.

Coefficient of variation of maximum pressure $\left(\mathrm{COV}_{\mathrm{pmax}}\right)$ is defined as:

$$
\mathrm{COV}_{\mathrm{pmax}}=\frac{\mathrm{STD}_{\mathrm{pmax}}}{\overline{\mathrm{p}_{\max }}} 100 \%,
$$

The standard deviation of maximum pressure:

$$
\operatorname{STD}_{\text {pmax }}=\sqrt{\frac{1}{N} \sum_{i=1}^{N}\left(p_{\operatorname{maxi}}-\overline{p_{\max }}\right)^{2}}
$$

where $\mathrm{N}$ is the cycle index and $\overline{\mathrm{p}_{\max }}$ is the mean value of maximum pressure of $\mathrm{N}$ cycle $\mathrm{p}_{\text {maxi }}$.

One of the indicators enabling the assessment of the stability of operation of an internal combustion engine may also be the probability density of selected parameters of its operation [29]. The function that allows us to express the probability of obtaining or occurrence of a specific value of the analyzed parameter is the probability density function. The maximum pressure probability density distribution is an indicator of the repeatability (probability of occurrence) of individual $p_{\max }$ values obtained for many analyzed test engine work cycles. This function can also be used as an indicator for assessing the stability of an internal combustion engine. It indicates, inter alia, the frequency of occurrence of the most frequently repeated $p_{\max }$ value, close to the average value, showing the repeatability of subsequent engine cycles. The $p_{\max }$ probability density is a normal (Gaussian) distribution in which the density function is symmetrical in relation to the mean value of the distribution [30].

Maximum pressure probability density:

$$
\Phi\left(\mathrm{p}_{\max }\right)=\frac{1}{\mathrm{STD}_{\mathrm{p} \max } \sqrt{2 \pi}} \exp \left(\frac{-\left(\mathrm{p}_{\operatorname{maxi}}-\overline{\mathrm{p}_{\max }}\right)^{2}}{2 \mathrm{STD}_{\mathrm{p} \max }^{2}}\right),
$$

\section{Results and Discussion}

\subsection{Combustion Characteristics}

The basic source of information about the combustion process in the cylinder of the research engine was the results of pressure measurement expressed in the function of crankshaft rotation. Figure $3 a, b$ presents the trace of pressure and heat release rates as well as the pressure rise rate in the cylinder of the engine co-combusting CNG with diesel fuel, for the entire range of gas shares, from $0 \%$ 
to $95 \%$. It can be seen that when the CNG energy share increases to $45 \%$, the pressure and heat release rate increase, and the combustion pressure in the cylinder of the research engine increases. Increasing the gas share above $45 \%$ causes a decrease in $\mathrm{p}_{\max }, \mathrm{HRRmax}$ and $\mathrm{dp} / \mathrm{d} \varphi$ due to ignition delay and prolonged combustion. The maximum value of $\mathrm{dp} / \mathrm{d} \varphi=0.76 \mathrm{MPa}$ /degree obtained for DCNG45 is lower than the value obtained for diesel by $0.27 \mathrm{MPa}$ /degree, and is lower than the permissible value for internal combustion engines of $1 \mathrm{MPa} /$ degree [31]. This proves the lack of so-called hard work, which can be harmful to the engine structure, especially during a long operation. DCNG90 and DCNG95 show a rapid slowdown in combustion and a decrease in the rate of heat release. It can be seen that, for gas shares up to $75 \%$, the dominant phase of the combustion process is the kinetic phase; combustion becomes too slow for larger CNG shares. Figure 3a shows a decrease in pressure in the compression stroke, along with an increase in the share of CNG gas. It results from the decrease in charge temperature in the intake manifold due to expansion of CNG gas from an injection pressure of 2 bar to atmospheric pressure. In addition, the pressure in the engine cylinder during compression is exponentially dependent on the specific heat ratio (which is the ratio of specific heat at constant pressure and constant volume), which for CNG gas is almost twice lower than for clean air.
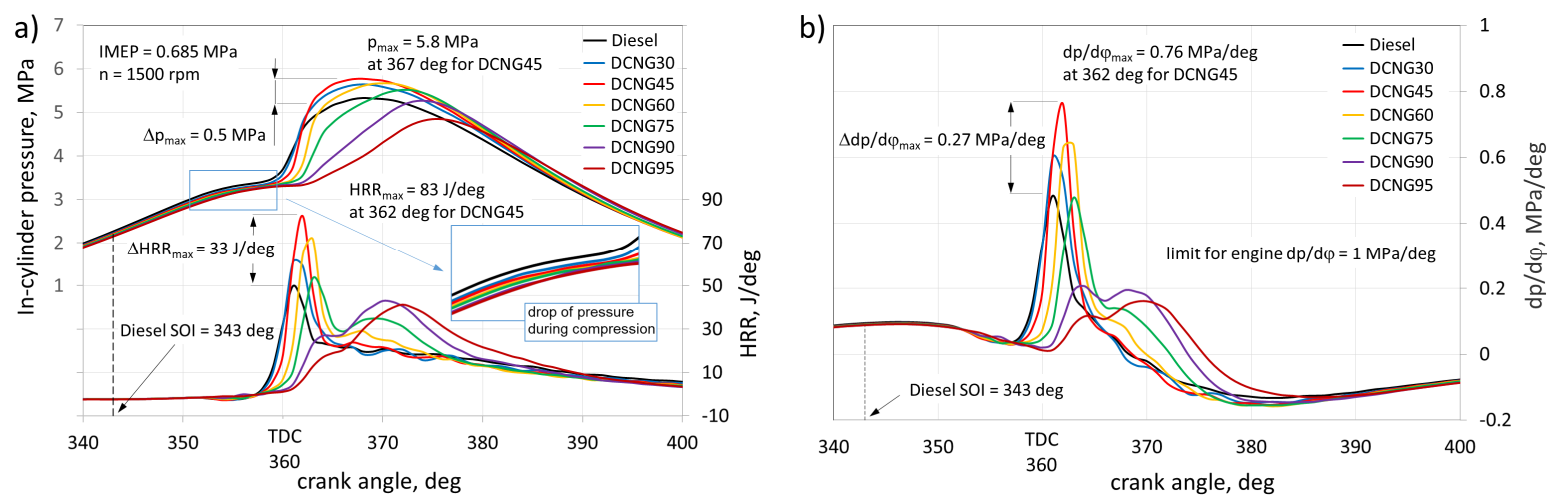

Figure 3. In cylinder combustion pressure, heat release rate (HRR) (a) and the rate of pressure rise $(\mathrm{dp} / \mathrm{d} \varphi)(\mathbf{b})$ for co-combustion of CNG and diesel fuel.

Figure 4 shows the course of the normalized heat release rate function in the combustion process, as well as the ignition delay and duration of combustion for the analyzed shares of CNG gas co-combusted with diesel fuel. The normalized heat released rate can be used to determine two very important indicators characterizing the combustion process in a piston engine. The first is the auto-ignition delay, which was defined as the time expressed in crankshaft rotation angles, between the injection of diesel fuel pilot-dose until $10 \%$ of the total heat was released. The second parameter is the duration of combustion, defined as the time from the release of $10 \%$ of the heat until the release of $90 \%$ of the heat. The phenomenon of spontaneous combustion is characterized by the initial period in which chemical reactions before ignition play a key role. The so-called chemical delay is counted from the beginning of these reactions. The physical phenomena that cause a delay in the ignition of a diesel engine are as follows: the breakdown of fuel into separate drops, the heating and evaporation of drops, and finally, the diffusion of fuel vapors into the air. The rate of combustion of liquid fuel is determined by the rate of its evaporation and mixing of the atomized fuel with air. The dynamics of these physical and chemical phenomena that occur at the start of the ignition process depend on the temperature. Shorter ignition delay in compression-ignition engines improves engine efficiency (less fuel consumption), improves engine adjustment (more effective control of injection timing), improves engine starting and reduces the pressure rise rate in the combustion process in the cylinder-which reduces operating noise and reduces loads on the crankshaft and piston pin. Based on the graphs prepared, it can be concluded that the addition of CNG gas increases the ignition delay of the combustible mixture in the cylinder of a dual-fuel engine and reduces the total duration of combustion. During the combustion of the mixture with the largest $95 \%$ share of CNG gas, compared to the combustion of diesel fuel, a 
$31.5 \%$ increase in ignition delay (ID) and a 55\% reduction in the burn duration (BD) was obtained. The increase in ignition delay was caused by the low self-ignition tendency of CNG gas expressed by high auto-ignition temperature and the low, close to 0 , cetane number. The reduction in the duration of combustion for significant CNG shares was caused, among other things, by the improvement in the homogeneity of the combustible mixture, which, being homogeneous throughout the cylinder volume, burned more intensively and faster.
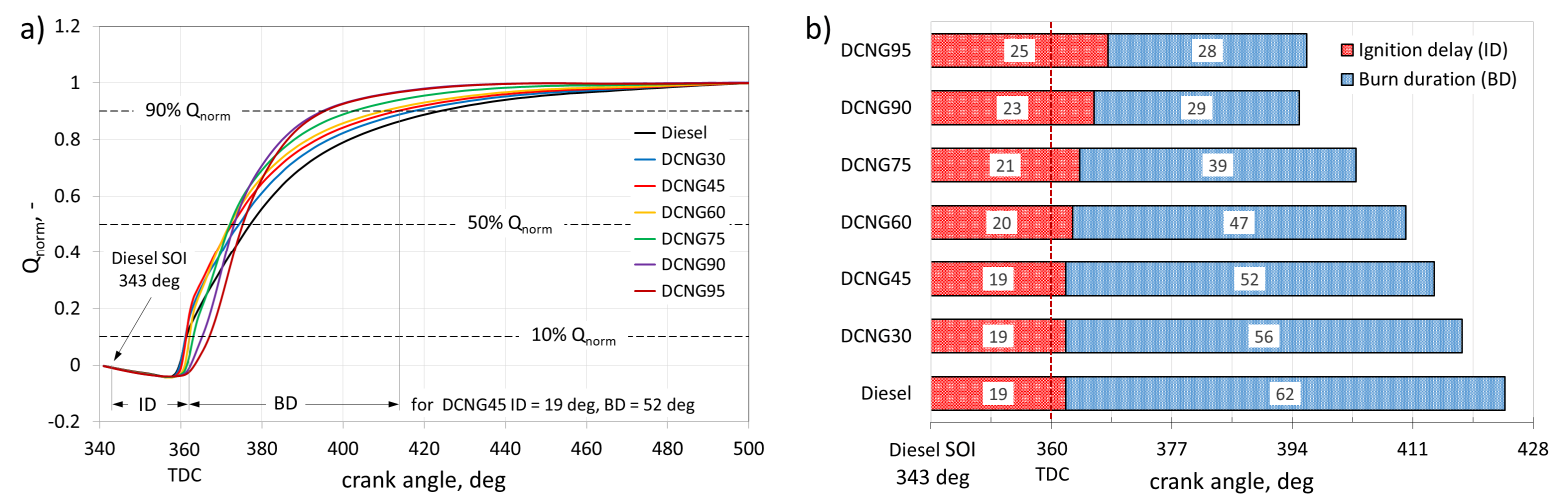

Figure 4. Normalized heat release (a) and ignition delay with burn duration (b) for analyzed share of CNG gas co-combusted with diesel fuel.

\subsection{Engine Stability}

The combustion engine's stability related to the cycle-by-cycle variation and the misfiring can be assessed on the basis of changes in the value of the coefficient of variation for maximum pressure $-\mathrm{COV}_{\mathrm{pmax}}$, and the probability density of the occurrence of the maximum pressure $-\Phi\left(\mathrm{p}_{\max }\right)$. Figure 5a shows the average maximum pressure and the $\mathrm{COV}_{\mathrm{pmax}}$ coefficient determined for the analyzed shares of CNG gas co-combusted with diesel fuel. Taking the $\mathrm{COV}_{\text {pmax }}$ factor as an indicator of the stability of dual-fuel engine operation, it can be seen that the most stable operation similar to diesel fuel combustion was ensured by diesel co-combusting with a $30 \%$ and $45 \%$ energy share of CNG gas $\left(\mathrm{COV}_{\mathrm{pmax}} \approx 1.2 \%\right)$. In the case of DCNG45, the highest value of the maximum combustion pressure $p_{\max }=5.75 \mathrm{MPa}$ was obtained. Figure $5 \mathrm{~b}$ presents the probability density of $\mathrm{p}_{\max }$ for a dual-fuel engine co-combusted diesel fuel with CNG gas. The maximum pressure probability density distribution $\left(\Phi\left(p_{\max }\right)\right)$, based on the normal distribution, is an indicator of the repeatability of individual $p_{\max }$ values obtained for the 200 analyzed test engine work cycles. Changes in the maximum pressure probability density indicate, among others, the repeatability of the average $p_{\max }$ value, which may be an indicator of stable operation of the test engine. In the case of a dual-fuel engine, the highest values of $p_{\max }$ probability density were obtained for DCNG30 and DCNG45. They were similar to those obtained during the combustion of diesel alone. The individual $p_{\max }$ values obtained, in 200 subsequent engine cycles and in the largest number of cycles, approached the mean value of $p_{\max }$ which proved the best repeatability of subsequent test engine work cycles. Those results confirmed earlier results of the analysis of the stability of dual-fuel engine operation based on changes in the $\mathrm{COV}_{\text {pmax }}$ coefficient. 

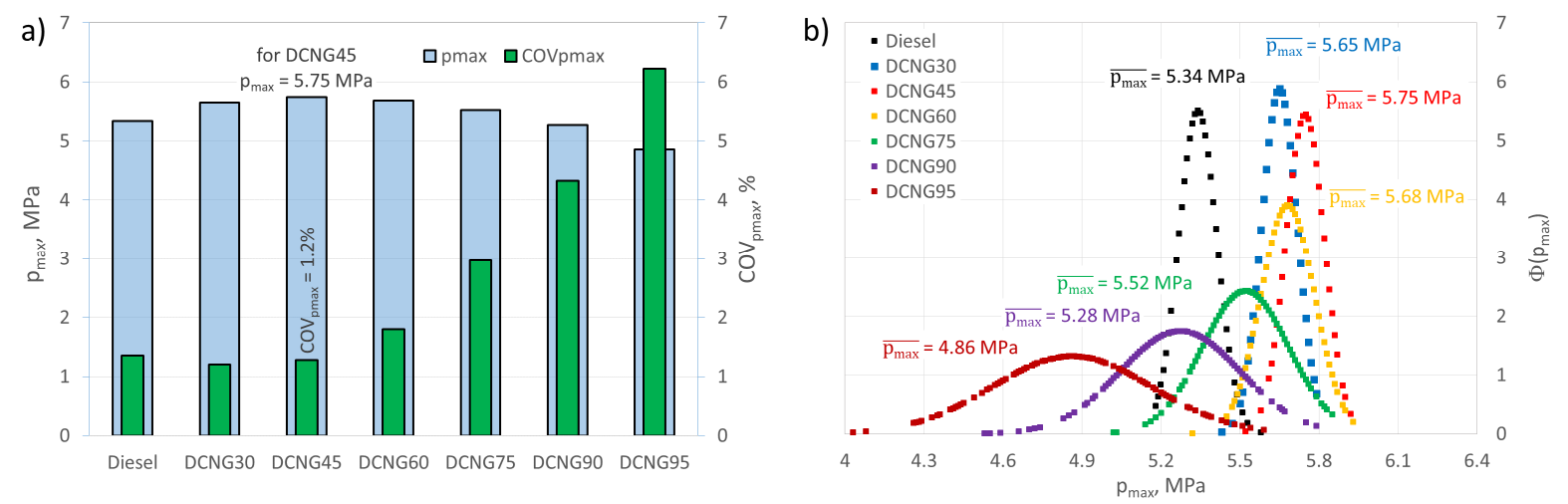

Figure 5. Mean maximum pressure, $\operatorname{COV}_{\text {pmax }}(\mathbf{a})$, and pressure probability density, $\Phi\left(\mathrm{p}_{\max }\right)$ (b) determined for the CNG shares co-combusted with diesel.

\subsection{Exhaust Emissions}

The test stand built as part of the work in this study enabled the measurement of the content of components in the dual-fuel engine exhaust gas. Concentrations of toxic exhaust components were measured: nitrogen oxide- $\mathrm{NO}, \mathrm{HC}-$ hydrocarbons and carbon monoxide $\mathrm{CO}$, as well as $\mathrm{CO}_{2}$ emissions. Figure 6a presents the impact of $\mathrm{CNG}$ gas on nitrogen oxide emissions. The main types of nitrogen oxides emitted by a piston engine are nitrogen oxide $(\mathrm{NO})$ and nitrogen dioxide $\left(\mathrm{NO}_{2}\right)$. The formation of nitric oxide in a piston engine is a direct result of the reaction between nitrogen $\left(\mathrm{N}_{2}\right)$ and oxygen $\left(\mathrm{O}_{2}\right)$, under the favorable conditions prevailing in the engine cylinder during the combustion process. The combustion processes mainly produce $\mathrm{NO}$, while $\mathrm{NO}_{2}$ is formed by the

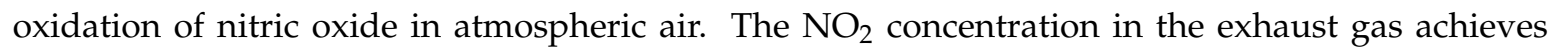
much lower concentrations compared to $\mathrm{NO}[32,33]$. Increasing the share of CNG co-combusted with diesel fuel causes an increase in nitric oxide emissions. The highest $\mathrm{NO}$ emission value of $242 \mathrm{ppm}$ was obtained for DCNG90. The conditions favoring the formation of NO during co-combustion of diesel fuel with CNG gas, whose share varied from $0 \%$ to $45 \%$, resulted from the intensification of the combustion process in the kinetic phase and the increase in the rate of heat release. However, after exceeding $45 \%$, the increase in nitrogen oxide emissions was the result of an increase in the availability of oxygen in the engine cylinder, unused in the prolonged combustion process. In addition, nitrogen-containing CNG gas increased its concentration in the cylinder and in the engine's exhaust gas. For DCNG95, there was a sudden decrease in NO emissions caused by a decrease in heat release in the disappearing kinetic stage of the combustion process. The intensification of the combustion process, presented by an increase in the heat release rate for DCNG30 and DCNG45, caused, compared to the combustion of diesel fuel alone, a reduction in HC emissions, despite an increase in ignition delay and a shorter combustion process (Figure 6a). After exceeding the $45 \%$ share of CNG gas, there was an increase in hydrocarbon emissions caused by a significant ignition delay and reduced burning time. The increase in THC emissions could be associated with the so-called crevice effect. Under these conditions, the fuel in the engine cylinder has no time to burn the fuel accumulated in the crevices of the combustion chamber (e.g., piston ring gaps). Figure $6 \mathrm{~b}$ presents the impact of the share of natural gas on $\mathrm{CO}_{2}$ and $\mathrm{CO}$ emissions of a dual-fuel engine powered by $\mathrm{CNG}$ and diesel. Research showed that increasing the share of CNG gas co-combusted with diesel fuel, compared to the combustion of diesel fuel, reduces carbon dioxide emissions by about $26 \%$ and almost completely reduces carbon monoxide in the exhaust gases of the engine. The reduction in $\mathrm{CO}_{2}$ and $\mathrm{CO}$ emissions was primarily due to the reduction in the total mass of fuel (containing carbon) supplied to the engine per one cycle of operation, due to the higher calorific value of CNG gas compared to diesel. In addition, the natural gas molecule contains less carbon compared to diesel (Table 3). Carbon monoxide (CO) is a toxic gas formed in a piston engine cylinder as a result of incomplete combustion of fuel, which may be caused by the lack of homogeneity of the air and fuel mixture [34]. In addition, $\mathrm{CO}$ reduction may result from 
an improvement in the homogeneity of the air and fuel mixture, together with the supply of gaseous fuel. This means that the combustion process in the engine tends to complete combustion, during which carbon monoxide is oxidized to carbon dioxide.
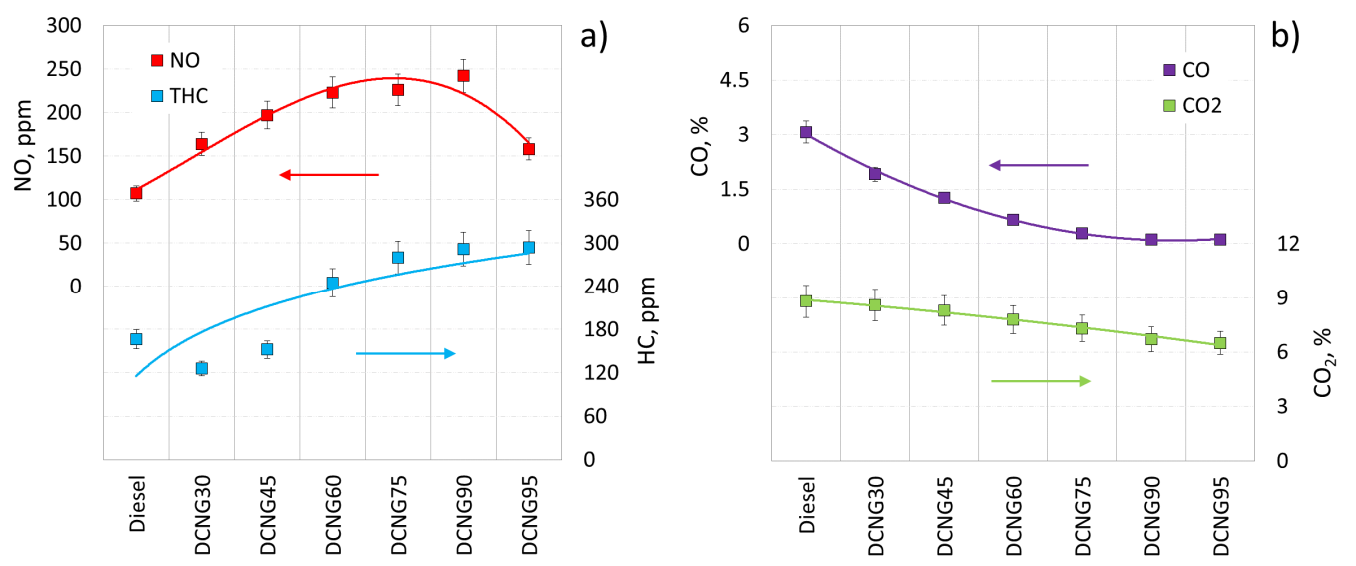

Figure 6. Emissions of $\mathrm{NO}$ and hydrocarbons ( $\mathrm{HC})(\mathbf{a})$, and $\mathrm{CO}$ and $\mathrm{CO}_{2}$ (b) for the dual fuel engine tested.

\section{Conclusions}

The use of natural gas to power a compression-ignition engine is one possible way to reduce the combustion of diesel fuel, which is considered one of the main causes of the greenhouse effect. This paper presents experimental research on a CI dual-fuel engine-powered by diesel fuel injected directly into the cylinder, and CNG gas injected into the intake manifold. The energy share of CNG gas co-fired with diesel fuel ranged from $0 \%$ to $95 \%$. Based on the analysis of test results, the following conclusions can be made:

(i) Increasing the energy share of CNG co-combusted with diesel in the $\mathrm{CI}$ engine from $0 \%$ to $45 \%$ increases the maximum combustion pressure, increases the rate of heat release and increases the combustion pressure. Increasing the CNG gas content above $45 \%$ causes a decrease in $\mathrm{p}_{\max }$, $\mathrm{HRR}_{\max }$ and $\mathrm{dp} / \mathrm{d} \varphi$, due to the significant ignition delay and prolonged combustion.

(ii) Co-combustion of increasing amounts of CNG gas with diesel fuel increases the ignition delay of the combustible mixture in the cylinder of a dual-fuel engine and reduces the total duration of combustion. During the combustion of the mixture with the largest, 95\% share of CNG gas, compared to the combustion of diesel alone, a 31.5\% increase in ignition delay (ID) and a 55\% reduction in the burn duration $(\mathrm{BD})$ was obtained.

(iii) When assessing the stability of a dual-fuel engine co-combusted diesel with natural gas based on the $\mathrm{COV}_{\text {pmax }}$ coefficient and pmax probability density, it can be seen that the most stable operation similar to diesel fuel combustion is provided by diesel co-combustion with the $30 \%$ and $45 \%$ energy shares of CNG.

(iv) Increasing the share of $\mathrm{CNG}$ co-combusted with diesel fuel causes an increase in nitric oxide emissions of a dual-fuel engine. The highest NO emission value of $242 \mathrm{ppm}$ was obtained for DCNG90.

(v) Compared to diesel fuel supply, co-combustion of this fuel with $30 \%$ and $45 \%$ CNG energy shares, despite the increase in ignition delay and shortening the combustion process, contributes to the reduction of $\mathrm{HC}$ emissions. After exceeding the $45 \%$ share of $\mathrm{CNG}$, there is an increase in hydrocarbon emissions.

(vi) Increasing the share of CNG gas co-combusted with diesel causes, compared to the combustion of diesel fuel, a decrease in carbon dioxide emissions by about $26 \%$ and an almost complete reduction of carbon monoxide in the exhaust gas of a dual-fuel engine. 
Author Contributions: Conceptualization, A.J., W.T. and K.G.-R.; Data curation, A.J., W.T. and K.G.-R.; Formal analysis, A.J.; Investigation, A.J., W.T. and K.G.-R.; Methodology, A.J. and W.T.; Writing-original draft, A.J.; Writing-review \& editing, W.T. and K.G.-R.

Funding: This research was funded by the Ministry of Science and Higher Education of Poland from the funds dedicated to scientific research No. BS/PB 1-100-3010/2019/P. Publication supported financially under Contract No. 944/P-DUN/2019 from funds of MNiSW intended for dissemination of science (DUN).

Conflicts of Interest: The authors declare no conflict of interest.

\section{Abbreviations}

$\begin{array}{ll}\text { IMEP } & \text { indicated mean effective pressure, } \mathrm{MPa} \\ \mathrm{BTE} & \text { brake thermal efficiency, \% } \\ \mathrm{BSFC} & \text { brake specific fuel consumption, } \mathrm{g} / \mathrm{kWh} \\ \mathrm{HRR} & \text { heat release rate, } \mathrm{J} / \text { degree } \\ \mathrm{COV}_{\mathrm{pmax}} & \text { coefficient of variation of maximum pressure, \% } \\ \mathrm{STD}_{\mathrm{pmax}} & \text { standard deviation of maximum pressure, } \mathrm{MPa} \\ \dot{\mathrm{m}}_{\mathrm{CNG}} & \text { CNG consumption per cycle, } \mathrm{mg} / \mathrm{cyc} \\ \dot{\mathrm{m}}_{\mathrm{D}} & \text { diesel fuel consumption per cycle, } \mathrm{mg} / \mathrm{cyc} \\ \mathrm{LHV} & \text { lower heating value of } \mathrm{CNG}, \mathrm{MJ} / \mathrm{kg} \\ \mathrm{LHV} & \text { lower heating value of diesel fuel, } \mathrm{MJ} / \mathrm{kg} \\ \mathrm{ID} & \text { ignition delay, degrees } \\ \mathrm{BD} & \text { burn duration, degrees } \\ \mathrm{V}_{\mathrm{d}} & \text { displaced cylinder volume, } \mathrm{cm}{ }^{3} \\ \mathrm{P} & \text { pressure, bar } \\ \mathrm{V} & \text { volume, cm }{ }^{3} \\ \mathrm{~N} & \text { engine speed, rpm } \\ \Phi\left(\mathrm{p}_{\mathrm{max}}\right) & \text { maximum pressure probability density } \\ \mathrm{CI} & \text { compression ignition engine } \\ \mathrm{CNG} & \text { compressed natural gas } \\ \mathrm{TDC} & \text { top dead centre } \\ \mathrm{SOI} & \text { start of injection } \\ \mathrm{NO} & \text { nitrogen oxides } \\ \mathrm{NO} & \text { nitrogen monoxide } \\ \mathrm{HC} & \text { hydrocarbons } \\ \mathrm{CO} & \text { carbon monoxide } \\ \mathrm{CO} & \text { carbon dioxide } \\ \mathrm{O}_{2} & \text { oxygenGreek letters } \\ \chi & \text { ratio of specific heats } \\ \varphi & \text { crank angle, degrees } \\ & \end{array}$

\section{References}

1. Kalghatgi, G. Development of Fuel/Engine Systems-The Way Forward to Sustainable Transport. Engineering 2019, 5, 510-518. [CrossRef]

2. Tutak, W.; Jamrozik, A. Validation and optimization of the thermal cycle for a diesel engine by computational fluid dynamics modeling. Appl. Math. Model. 2016, 40, 6293-6309. [CrossRef]

3. Tutak, W.; Jamrozik, A. Generator gas as a fuel to power a diesel engine. Therm. Sci. 2014, 18, $206-216$. [CrossRef]

4. Park, H.; Shim, E.; Bae, C. Improvement of combustion and emissions with exhaust gas recirculation in a natural gas-diesel dual-fuel premixed charge compression ignition engine at low load operations. Fuel 2019, 235, 763-774. [CrossRef]

5. Manigandan, S.; Gunasekar, P.; Devipriya, J.; Nithya, S. Emission and injection characteristics of corn biodiesel blends in diesel engine. Fuel 2019, 235, 723-735. [CrossRef]

6. Directive 2009/28/EC of the European Parliament and of the Council. 23 April 2009. Available online: http://eur-lex.europa.eu/legal-content/PL/ALL/?uri=celex\%3A32009L0028/ (accessed on 10 July 2019). 
7. Braungardt, S.; Bürger, V.; Ziege, J.; Bosselaar, L. How to include cooling in the EU Renewable Energy Directive? Strategies and policy implications. Energy Policy 2019, 129, 260-267. [CrossRef]

8. Kuszewski, H. Experimental investigation of the autoignition properties of ethanol-biodiesel fuel blends. Fuel 2019, 235, 1301-1308. [CrossRef]

9. Jamrozik, A.; Tutak, W.; Gruca, M.; Pyrc, M. Performance, emission and combustion characteristics of CI dual fuel engine powered by diesel/ethanol and diesel/gasoline fuels. J. Mech. Sci. Technol. 2018, 32, 2947-2957. [CrossRef]

10. Jamrozik, A.; Tutak, W.; Pyrc, M.; Gruca, M.; Kocisko, M. Study on co-combustion of diesel fuel with oxygenated alcohols in a compression ignition dual-fuel engine. Fuel 2018, 21, 329-345. [CrossRef]

11. Lounici, M.S.; Boussadi, A.; Loubar, K.; Tazerout, M. Experimental investigation on NG dual fuel engine improvement by hydrogen enrichment. Int. J. Hydrog. Energy 2014, 39, 21297-21306. [CrossRef]

12. Verma, S.; Das, L.M.; Bhatti, S.S.; Kaushik, S.C. A comparative exergetic performance and emission analysis of pilot diesel dual-fuel engine with biogas, CNG and hydrogen as main fuels. Energy Convers. Manag. 2017, 151, 764-777. [CrossRef]

13. Wang, Z.; Du, G.; Wang, D.; Xu, Y.; Shao, M. Impact of pilot diesel ignition mode on combustion and emissions characteristics of a diesel/natural gas dual fuel heavy-duty engine. Fuel 2016, 167, 248-256. [CrossRef]

14. Nithyanandan, K.; Lin, Y.; Donahue, R.; Meng, X.; Zhang, J.; Lee, C.F. Characterization of soot from diesel-CNG dual-fuel combustion in a CI engine. Fuel 2016, 184, 145-152. [CrossRef]

15. Stelmasiak, Z.; Larisch, J.; Pietras, D. Selected problems of adaptation car diesel engine for dual fuel supplying. Combust. Engines 2015, 162, 1021-1029.

16. Papagiannakis, R.G.; Rakopoulos, C.D.; Hountalas, D.T.; Rakopoulos, D.C. Emission characteristics of high speed, dual fuel, compression ignition engine operating in a wide range of natural gas/diesel fuel proportions. Fuel 2010, 89, 1397-1406. [CrossRef]

17. Papagiannakis, R.G.; Krishnan, S.R.; Rakopoulos, D.C.; Srinivasan, K.K.; Rakopoulos, C.D. A combined experimental and theoretical study of diesel fuel injection timing and gaseous fuel/diesel mass ratio effects on the performance and emissions of natural gas-diesel HDDI engine operating at various loads. Fuel 2017, 202, 675-687. [CrossRef]

18. Meng, X.; Tian, H.; Long, W.; Zhou, Y.; Bi, M.; Tian, J.; Lee, C.F. Experimental study of using additive in the pilot fuel on the performance and emission trade-offs in the diesel/CNG (methane emulated) dual-fuel combustion mode. Appl. Therm. Eng. 2019, 157, 113718. [CrossRef]

19. Ryu, K. Effects of pilot injection timing on the combustion and emissions characteristics in a diesel engine using biodiesel-CNG dual fuel. Appl. Energy 2013, 111, 721-730. [CrossRef]

20. Ryu, K. Effects of pilot injection pressure on the combustion and emissions characteristics in a diesel engine using biodiesel-CNG dual fuel. Energy Convers. Manag. 2013, 76, 506-516. [CrossRef]

21. Bari, S.; Hossain, S.N. Performance of a diesel engine run on diesel and natural gas in dual-fuel mode of operation. Energy Procedia 2019, 160, 215-222. [CrossRef]

22. Liu, J.; Yang, F.; Wang, H.; Ouyang, M.; Hao, S. Effects of pilot fuel quantity on the emissions characteristics of a CNG/diesel dual fuel engine with optimized pilot injection timing. Appl. Energy 2013, 110, 201-206. [CrossRef]

23. Karabektas, M.; Ergen, G.; Hosoz, M. The effects of using diethylether as additive on the performance and emissions of a diesel engine fuelled with CNG. Fuel 2016, 115, 855-860. [CrossRef]

24. Jamrozik, A. The effect of the alcohol content in the fuel mixture on the performance and emissions of a direct injection diesel engine fueled with diesel-methanol and diesel-ethanol blends. Energy Convers. Manag. 2017, 148, 461-476. [CrossRef]

25. Repair Instructions. Bosch Emissions Analysis BEA 150, BEA 250, BEA 350. Available online: https: //equiposbosch.es/ (accessed on 14 August 2019).

26. Gilowski, T.; Stelmasiak, Z. Impact of symmetrical division of initial dosage diesel oil on the selected thermodynamic parameters of the working medium and operation parameters dual fuel engine fuelled CNG. Combust. Engines 2013, 154, 879-886.

27. Stelmasiak, Z. Selected problems of application of natural gas to CI engine. Arch. Automot. Eng. 2006, 1, 13-30. 
28. Chen, Z.; Yao, C.; Yao, A.; Dou, Z.; Wang, B.; Wei, H.; Liu, M.; Chen, C.; Shi, J. The impact of methanol injecting position on cylinder-to-cylinder variation in a diesel methanol dual fuel engine. Fuel 2017, 191, 150-163. [CrossRef]

29. Jamrozik, A.; Tutak, W.; Gnatowska, R.; Nowak, Ł. Comparative analysis of the combustion stability of diesel-methanol and diesel-ethanol in a dual fuel engine. Energies 2019, 12, 971. [CrossRef]

30. Taylor, J.R. Introduction to Error Analysis: The Study of Uncertainties in Physical Measurements; University Science Books: Sausalito, CA, USA, 1997.

31. Heywood, J.B. Internal Combustion Engine Fundamentals; McGraw-Hill Book Company: New York, NY, USA, 1988.

32. Żółtowski, A. Influence of after-treatment systems on $\mathrm{NO}_{2}$ emissions in diesel engines. Combust. Engines 2017, 170, 24-29.

33. Olsen, D.B.; Kohls, M.; Arney, G. Impact of oxidation catalysts on exhaust $\mathrm{NO}_{2} / \mathrm{NO}_{\mathrm{x}}$ ratio from lean-burn natural gas engines. J. Air Waste Manag. Assoc. 2010, 60, 867-874. [CrossRef]

34. Darade, P.M.; Dalu, R.S. Performance and emissions of internal combustion engine fuelled with CNG-A Review. Int. J. Eng. Innov. Res. 2012, 1, 473-477.

(C) 2019 by the authors. Licensee MDPI, Basel, Switzerland. This article is an open access article distributed under the terms and conditions of the Creative Commons Attribution (CC BY) license (http://creativecommons.org/licenses/by/4.0/). 